\title{
Mysterious and elaborated: the reproductive behavior of the rhomboid mojarra, Diapterus rhombeus (Cuvier, 1829), in Brazilian mangrove habitats
}

\author{
José Amorim Reis-Filho ${ }^{1,2^{*}}$ and Antoine O. H. C. Leduc ${ }^{1}$
}

\begin{abstract}
Many fish species have behavioral traits related to reproduction that aim to improve egg conditions and survival of early life stages. Here, we provide the first detailed description of reproductive strategies performed by the rhomboid mojarra, Diapterus rhombeus. We based this description on several mating events, which occurred in mangroves located in Todos os Santos Bay, Brazil. These spawning events occurred at the mangrove fringe in the month of August in 2013 and 2014, which suggests that these spawning events occur predictably in space and time. Two principal behavioral tactics were observed and involved breeding aggregation and a unique nest-clearing behavior. Following these behaviors, many fish exhibited an extreme lethargic state during which they took refuge amidst mangrove roots. Overall, these observations revealed an unexpected and uncommon set of behaviors in an otherwise well-studied species. The present study not only highlights basic gaps in our understanding of estuarine species but also suggests that future investigations are poised to yield exciting and insightful findings.
\end{abstract}

Keywords: Diapterus rhombeus, Reproduction, Behavioral expression, Mangrove habitat, Conservation

\section{Background}

Improving our knowledge of the behavioral and life history traits of marine fishes has often resulted in a better understanding of the factors regulating their productivity and thereby has provided managers and conservationists with much-needed information for guiding sustainable exploitation [1-3]. While documenting the spatiotemporal characteristics associated with the reproductive behavior of many organisms is common, the results generated must be thoroughly understood in terms of the population structure and habitat requirement of the species if helpful guidance for management is sought [4]. For example, teleost fishes are characterized by a wide range of reproductive behaviors, ranging from large spawning aggregations [5] to an absence of parental care

\footnotetext{
*Correspondence: amorim_agua@yahoo.com.br

${ }^{1}$ Instituto de Biologia, Universidade Federal da Bahia, Campi Ondina,

Salvador, BA, Brazil

Full list of author information is available at the end of the article
}

or, alternatively, to uniparental or biparental care $[6,7]$. Thus, it is imperative to understand that each of these behavioral traits is able to affect population trajectories in distinct ways. For example, improving reproductive success (including offspring survival) requires individuals to adjust their phenotype to either face environmental changes and/or to meet specific requirements associated with their life cycle (e.g., breeding period). In turn, the relative success of each of these behavioral patterns may have substantial consequences for population growth and permanence in the wild [8].

Maximizing lifetime reproductive success often requires that individuals undergo a range of behavioral modalities (e.g., courtship, mating, and territorial defense), each of which may be regulated by the prevailing environmental context [9-11]. For example, in many marine fish species, suitable spawning grounds constitute a resource of prime importance to successfully reproduce [12-14]. Thus, accurate records and identifications of these spawning habitats are crucial to promote 
useful conservation practices and sustainable fisheries, and given the complexity of many spawning systems (i.e., often involving a range of behaviors as detailed above), a thorough understanding of how these sites are used for spawning also becomes essential [5]. However, for most estuarine systems, given their high sediment loading, these habitats are visually impenetrable, which often prevents detailed observations from being conducted [but see 15]. Thus, this common estuarine characteristic implies that only indirect evaluation of habitat requirements can be made for most species.

The rhomboid mojarra (Diapterus rhombeus) is a common and widely distributed marine and estuarine fish whose presence in the Western Atlantic spans from Florida to Brazil [16]. This species is one of the most abundant demersal fishes of embayments located in Central and South America. Adults can reach up to $210 \mathrm{~mm}$ in total length (TL) [17] and are usually found aggregating in small groups (e.g., 20 individuals). The diet of $D$. rhombeus is mainly composed of benthic and pelagic invertebrates, including Polychaeta and Crustacea [18, 19]. Along the Brazilian coasts, this species typically occurs in mangroves (dominated by either mature forests or fringe fragments), in estuaries and in relatively shallow bays (depth of 0.2-30 m; [15]). Despite the low depth at which $D$. rhombeus is typically found, this species is adapted to low-visibility conditions resulting from high levels of suspended sediments, i.e., those which often characterize estuarine environments. As such, the conditions under which this species occurs have often impeded researchers and managers from studying its ecology and behavior. While various studies have described the reproductive cycle of the rhomboid mojarra [17, 18, 20,21], we have scant information on the breeding behavior of this species in the wild. To some extent, this deficiency may be palliated by behavioral studies conducted in captivity; however, biases associated with this behavioral trait are bound to occur as a result of the venue (non-natural conditions) under which observations were conducted.

To understand the processes governing the breeding behavior of this abundant tropical fish, we conducted directed observation in the wild. While the high-turbidity contexts under which this species occurs often impede conducting direct observations, the behavior described here results from observations taken in clear-water (i.e., low-turbidity) mangroves.

\section{Materials and methods}

In 2013 and 2014, we carried out monthly dives in 10 mangroves characterized by the presence of Avicennia schaueriana and Rhizophora mangle forests. Each of these free dives lasted approximately $6 \mathrm{~h}$ and was restricted to a given sampling area. Observations were conducted between 0700 am and 1100 am, which corresponded to the occurrence of the reproductive strategies. The records were conducted while snorkeling in the mangrove sites located on two islands within Todos os Santos Bay (TSB) (i.e., Itaparica Island and Frade Island; approx. $\left.12^{\circ} 50^{\prime} \mathrm{S}, 38^{\circ} 50^{\prime} \mathrm{W}\right)$, which is itself located off the Brazilian central coast. The total embayment of TSB is nearly $1100 \mathrm{~m}^{2}$.

In each of the 2 years of study, we observed shoals containing 350 to $700 \mathrm{D}$. rhombeus individuals estimated to range in size from 6 to $18 \mathrm{~cm}$ TL. Of these, 35 and 50 individuals (2013 and 2014, respectively) were caught using a manual trap, allowing us to determine the gonadal stage of each of the captured individuals. For this purpose, we used a stereomicroscope or, when possible, a macroscopic approach. For instance, females ripe for spawning present intense yellow color at the gonads and a high concentration of surface blood vessels and oocytes, while over $70 \%$ of the celomatic cavity is occupied by gonads in their mature stage [22]. Of the fish caught in 2013 and 2014, 89.7 and 90.4\% presented mature gonads, respectively.

For our behavioral observations, we used the 'focal animal' approach, which involved documenting any observable behaviors [23, 24]. Specifically, an observer (JAR-F) positioned himself at approximately $1.5-2.0 \mathrm{~m}$ from the focal individual to conduct observations. The records were made on plastic sheets and by using a portable video camera (GoPro ${ }^{\mathrm{TM}}$ Hero $3+$ with the resolution set to 12 megapixels).

\section{Results}

In seven and eight of the 10 mangrove sites (in 2013 and 2014, respectively), we observed $D$. rhombeus performing intense mating behavior. The behavioral repertoire of the rhomboid mojarra includes individual and group movements, which is reminiscent of a breeding aggregation. This behavior was then followed by a nest-clearing behavior. We observed these behaviors for approximately $3 \mathrm{~h}$, during which fish exhibited an uncommon and peculiar swimming behavior (see Additional file 1: Supplementary video at https://vimeo.com/262987523). This behavior may be characterized as a series of seemingly erratic and abrupt movements, which includes frequent shifts in direction and high-speed bursts of swimming among the mangrove prop roots and propagules. Surprisingly, after this behavioral display, many individuals exhibited yet another uncommon behavior, in which each individual voluntarily "trapped" itself among mangrove prop roots while continuing to breathe (Fig. 1). Individuals remained in this state and confined among root structures for a period ranging from 2 to $15 \mathrm{~min}$ (average of $7.4 \mathrm{~min}$ ) (Fig. 2a). Approximately $40 \%$ of all individuals 

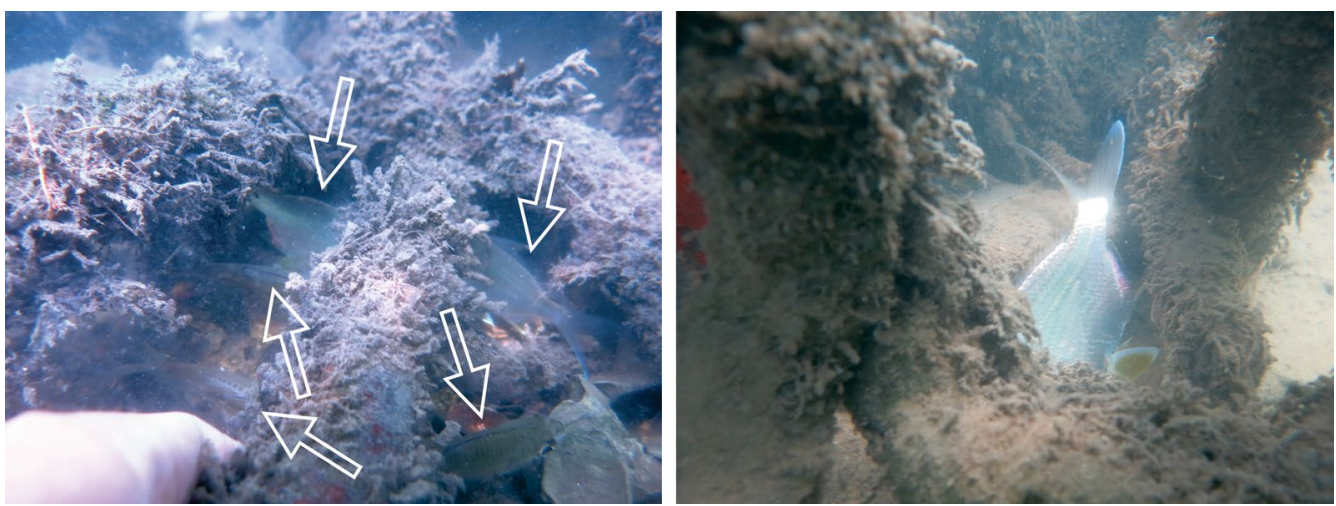

Fig. 1 Individuals of Diapterus rhombeus that voluntarily trapped themselves among prop roots following the breeding aggregations. White arrows show fish concealed locations
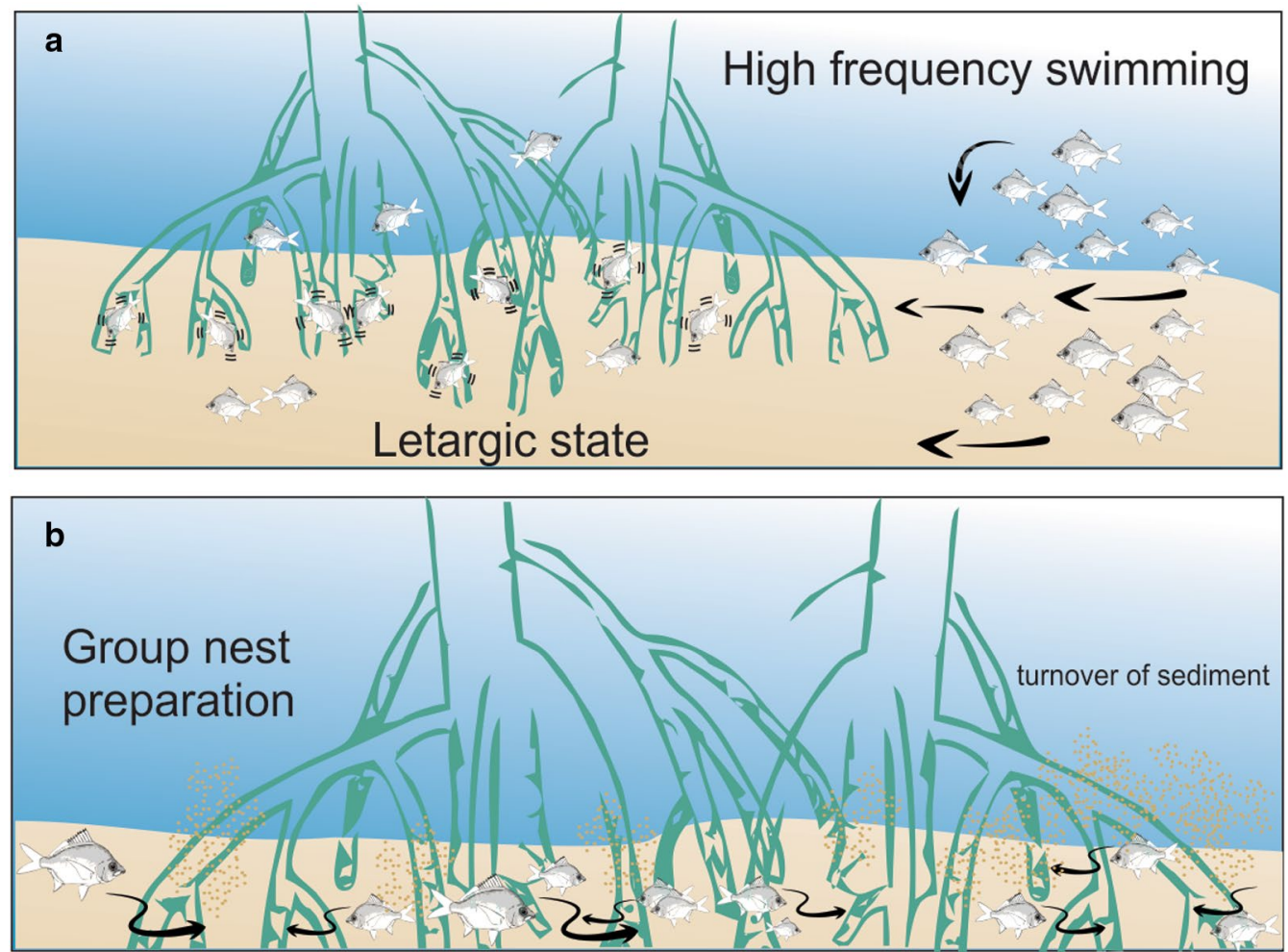

Fig. 2 Schematic view of rhomboids mojarra undergoing distinct parts involved in their reproductive event. a Individuals underwent seemingly disoriented rapid swimming, following which many individuals voluntarily trapped themselves among the prop roots (green structures). $\mathbf{b}$ Thereafter these individuals repetitively swam under the mangrove roots and thereby promoted sediments turnover

who engaged in the breeding aggregation entered this apparently lethargic state.

During this reproductive event, we observed another behavior reminiscent of group nest preparation, which involved the clearing of the substrate by several individuals. Indeed, both in 2013 and 2014, several $D$. rhombeus individuals were repeatedly recorded undergoing a peculiar behavior, which involved repetitively swimming under the mangrove roots and thus promoting sediment turnover along their path (see Additional file 1: Supplementary video at https://vimeo.com/26298 7523 and Fig. 2b). These events lasted for $0.5 \pm 0.3 \mathrm{~min}$ 
(mean $\pm \mathrm{SE}$ ), and because of sediment suspension, the eggs potentially released over the cleared surfaces were nearly undistinguishable from sediment particles. Approximately $35 \%$ of observed fish involved in the breeding aggregation exhibited this behavior.

\section{Discussion}

Our observations are the first qualitative description of the reproductive behavior in the rhomboid mojarra (Diapterus rhombeus). This species is one of the most common and well-studied estuarine species found along the Brazilian coast. In Brazilian waters, rhomboid mojarras are known to typically spawn during the summer months (i.e., December to April; [20]), but may also spawn in other periods, for instance, from August to November [17]. The distance between these studies is nearly $2500 \mathrm{~km}$, which may explain why such differences in the reproductive period exist (e.g., regional environmental characteristics such as water temperature and salinity). In the Brazilian central coast (present study), the environmental variables are similar to those reported by [17]. Previous observations made on D. rhombeus revealed that adults typically spawn in areas deeper than $10 \mathrm{~m}$, whereas juveniles use the shallow waters of estuaries, bays and mangroves. Moreover, [20]) suggested that smaller individuals (i.e., $<150 \mathrm{~mm} \mathrm{TL}$ ) present evidence of previous spawning events. However, here, we show that shallow habitats, such as mangroves, are highly suitable spawning habitats for this species.

The sequence of events observed herein, along with the video footage we produced, allows the subdivision of the behavior into distinct modalities. First, the apparently disoriented high-speed swimming of individuals in group is indicative of a breeding aggregation. Incidentally, this behavior appears to detract other typical mangrove fishes (e.g., snappers, sea bass and pilchards) from the area, as these species were never observed during these breeding aggregations. Second, we observed a sequence of repetitive movements beneath the roots (i.e., nest clearing), leading many fish into a 'numbness' or lethargic state.

Distinct hypotheses can be put forward to explain the observed aggregations of mojarras and their unexpected lethargic behavior. For example, these fish may spawn in shallow areas that are difficult for most predators to access [25]. Furthermore, the presence of streams and mangrove creeks near a spawning event (JAR-F, unpublished data) may result in increased food availability (i.e., from the inputs of organic matter; $[26,27])$, which may thereafter be essential to support a large aggregation of offspring. By itself, the lethargic state in which fish were found hiding themselves among prop roots may be a consequence of their state of fatigue after spawning, in which fish would be particularly vulnerable to predation. Thus, it appears that mating interactions are plausible explanations for the observed aggregations. This theory is further corroborated by the fact that most of the individuals captured were sexually mature. Moreover, the seemingly erratic and high-velocity swimming we observed is typical of groups undergoing nest preparation [28], which also involves modifying the benthic habitat to accommodate the eggs to be released [29]. Nest builders of marine substrata typically clean nesting areas by removing and/ or farming preferred substratum before egg release [30, 31]. However, given that nest preparation behavior seldom occurred during our observations, group breeding aggregations appear to be the main reproductive strategy that rhomboid mojarras undergo in shallow water mangroves. Overall, breeding in shallow-water mangrove habitats provides the main advantage of reduced predation risk for offspring and spawning adults as well as ample resources for newborns.

While it is difficult to conclusively establish the precise functions of the seemingly complex behavioral display presented by $D$. rhombeus, the success (i.e., abundance and wide distribution) of this species in numerous embayments of the Brazilian coast is tied to its life history strategies (see [32-35]). Thus, it is important to consider that the observed reproductive strategies may not necessarily be common in $D$. rhombeus, as this species is able to adjust to a wide range of conditions and thereby show plasticity in its behavior [34], a key element to exploit a wide range of environmental conditions. Therefore, whether this behavior occurs in turbid estuarine conditions remains to be determined, and to this effect, multibeam sonar may be able to provide a definite answer.

To protect this species (and its habitat), it is paramount to understand its reproductive behavior and how it is tied to habitat requirements. Notably, the rhomboid mojarra is an important component of the artisanal fishing sector in the South American continent [33, 36-38] and may suffer unforeseen effects from small-scale fisheries, which may be difficult to properly assess. An understanding of this organism's behavior and habitat requirements is an important step in this direction.

\section{Additional file}

Additional file 1. Breeding exciment of Diapterus rhombeus.

Abbreviations

TL: total length; cm: centimeter; TSB: Todos os Santos Bay; JAR-F: José Amorim Reis-Filho; SE: standard error. 


\section{Authors' contributions}

JAR-F conceived the study and performed the dives and sample collection as well as wrote the manuscript. $\mathrm{AOHL}$ wrote and contributed to building the manuscript and revised draft versions. Both authors read and approved the final manuscript.

\section{Author details}

${ }^{1}$ Instituto de Biologia, Universidade Federal da Bahia, Campi Ondina, Salvador, BA, Brazil. ${ }^{2}$ Laboratório de Biologia Pesqueira - Manejo dos Recursos Aquáticos (UFPA), Av. Perimetral 2651, Terra Firme, 66040170 Belém, PA, Brazil.

\section{Acknowledgements}

We thank the ICHTUS Soluções em Meio Ambiente Ltda. for allowing us to use this underwater video footage for our analyses and all fishers of Itaparica Island and Frade Island for valuable information. We also thank Diane Aquino for assistance and advice in the field. AOHCL acknowledges receiving a PNPD scholarship from CAPES.

\section{Competing interests}

The authors declare that they have no competing interests.

\section{Availability of data and materials}

All data generated or analyzed during this study are included in this published article.

\section{Consent for publication}

Not applicable.

\section{Ethics approval and consent to participate}

Not applicable.

\section{Funding}

Not applicable.

\section{Publisher's Note}

Springer Nature remains neutral with regard to jurisdictional claims in published maps and institutional affiliations.

\section{Received: 15 February 2018 Accepted: 28 May 2018}

Published online: 31 May 2018

\section{References}

1. Semmens J, Buxton C, Forbes E, Phelan M. Spatial and temporal use of spawning aggregation sites by the tropical sciaenid Protonibea diacanthus. Mar Ecol Prog Ser. 2010;403:193-203.

2. Goethel DR, Quinn TJ, Cadrin SX. Incorporating spatial structure in stock assessment: movement modeling in marine fish population dynamics. Rev Fish Sci. 2011;19:119-36.

3. Navarrete-Fernández T, Landaeta MF, Bustos CA, Pérez-Matus A. Nest building and description of parental care behavior in a temperate reef fish, Chromis crusma (Pisces: Pomacentridae). Rev Chil Hist Nat. 2014;87:1-9.

4. Lowerre-Barbieri S, Villegas-Ríos D, Walters S, Bickford J, Cooper W. Spawning site selection and contingent behavior in common snook, Centropomus undecimalis. PLoS ONE. 2014. https://doi.org/10.1371/journ al.pone.0101809.

5. van Overzee HMJ, Rijnsdorp AD. Effects of fishing during the spawning period: implications for sustainable management. Rev Fish Biol Fish. 2014 https://doi.org/10.1007/s11160-014-9370-x.

6. Blumer LS. A bibliography and categorization of bony fishes exhibiting parental care. Zool J Linn Soc. 1982;75:1-2.

7. Webb JN, Houston Al, McNamara JM, SzéKely T. Multiple patterns of parental care. Anim Behav. 1999;58:983-93.

8. Smith C, Wooton RJ. The cost of parental care in teleost fishes. Rev Fish Biol Fish. 1995;5:7-22.

9. Darwin CR. On the origin of species by means of natural selection, or the preservation of favoured races in the struggle for life. London: Murray; 1859.
10. Alcock J. Animal behavior: an evolutionary approach. Sunderland: Sinauer Associates; 2009.

11. Stamps JA. Individual differences in behavioural plasticities. Biol Rev. 2015. https://doi.org/10.1111/brv.12186.

12. Baylis JR. The evolution of parental care in fishes, with reference to Darwin's rule of male sexual selection. Environ Biol Fish. 1981;6:223-51.

13. Lindstrom K, Lugli M. A quantitative analysis of the courtship acoustic behaviour and sound patterning in male sand goby, Pomatoschistus minutus. Environ Biol Fish. 2000;58:411-24.

14. Large DA, Diez G, Drewery J, Laurans M, Pilling GM, Reid DG, Reinert J, South AB, Vinnichenko VI. Spatial and temporal distribution of spawning aggregations of blue ling (Molva dypterygia) west and northwest of the British Isles. ICES J Mar Sci. 2010;67:494-501.

15. Reis-Filho JA, Giarrizzo T, Barros F. Tidal migration and cross-habitat movements of fish assemblage whithin a mangrove ecotone. Mar Biol. 2016. https://doi.org/10.1007/s00227-016-2885-z.

16. Gilmore RG Jr, Greenfield DW. Gerreidae. Mojarras. In: Carpenter KE, editor The living marine resources of the Western Central Atlantic. Vol. 3: Bony fishes part 2 (Opistognathidae to Molidae), sea turtles and marine mammals. FAO species identification guide for fishery purposes and American Society of Ichthyologists and Herpetologists Species Publication No. 5. Rome: FAO, p 1506-1521. 2002

17. Bezerra RS, Vieira VLA, Santos AJG. Ciclo reprodutivo da carapeba prateada Diapterus rhombeus (Cuvier, 1829), no litoral de Pernambuco Brasil. Trop Ocean. 2001;29:67-78.

18. Santos ACC, Araújo FG. Hábitos alimentares de três espécies de Gerreidae (Osteichthyes, Perciformes) na Baía de Sepetiba. Arq Bio Tech. 1997;40:359-68.

19. Pessanha ALM, Araújo FG. Spatial and size feeding niche partitioning of the rhomboid mojarra Diapterus rhombeus (Cuvier, 1829) in a tropical Brazilian Bay. Mar Biol Res. 2012;8:273-83.

20. Chaves PTC, Otto G. Aspectos biológicos de Diapterus rhombeus (Cuvier) (Telostei, Gerreidae) na Baía de Guaratuba, Paraná, Brasil. Rev Bras Zoo. 1998;15:289-95.

21. Ayala-Pérez LA, Gómez-Montes BA, Miranda J. Distribucion, abundancia y parâmetros poblacionales de la mojarra Diapterus rhombeus (Pisces: Gerreidae) en la Laguna de Términos, Campeche, México. Rev Biol Trop. 2001:49:63542.

22. Vazoller AEA. Biologia da reprodução de peixes teleósteos. Maringá-PR: EDUEM: 169 p. 1996.

23. Altmann J. Observational study of behaviour: sampling methods. Behaviour. 1974:49:227-65.

24. Nunes JAC, Sampaio CLS, Barros F, Leduc AOHC. Plastic debris collars: an underreported stressor in tropical reef fishes. Mar Pollut Bull. 2017. https ://doi.org/10.1016/j.marpolbul.2017.10.076.

25. Klimley AP, Nelson DR. Diel movement patterns of the scalloped hammerhead shark (Sphyrna lewini) in relation to el Bajo Espiritu Santo: a refuging central-position social system. Behav Ecol Sociobiol. 1984;15:45-54

26. Bessudo S, Soler GA, Klimley AP. Residency of the scalloped hammerhead shark (Sphyrna lewini) at Malpelo Island and evidence of migration to other islands in the eastern tropical Pacific. Environ Biol Fish. 2001;91:165-76.

27. Ketchum JT, Hearn A, Klimley AP. Seasonal changes in movements and habitat preferences of the scalloped hammerhead shark (Sphyrna lewini) while refuging near an oceanic island. Mar Biol. 2014;161:755-67.

28. Tyler WA. The adaptive significance of colonial nesting in a coral-reef fish. Anim Behav. 1995;49:949-66.

29. Francini-Filho RB, Coni EOC, Ferreira CM, Alves AC, Rodrigues LS, AmadoFilho GM. Group nest clearing behaviour by the sergeant major Abudefdul saxatilis (Pisces: Pomacentridae). Bull Mar Sci. 2012:88:195-6.

30. Unger LM, Sargent RC. Allopaternal care in the fathead minnow, Pimephales promelas: females prefer males with eggs. Behav Ecol Sociobiol. 1988;23:27-32

31. Klumpp DW, Polunin NVC. Partitioning among grazers of food resources within damselfish territories on a coral reef. J Exp Mar Biol Ecol. 1989:125:145-69.

32. Reis-Filho JA, Nunes JACC, Ferreira A. Estuarine ichthyofauna of the Paraguaçu River, Todos os Santos Bay, Bahia, Brazil. Biot Neot. 2010;10:301-12.

33. Dias JF, Gonçalves AM, Fernandez WS, Silbiger HLN, Fiadi CB, Schmidt TCS. Ichthyofauna in an estuary of the Mataripe area, Todos os Santos Bay, Bahia, Brazil. Braz J Ocean. 2011·59·75-95. 
34. Costa MR, Albieri RJ, Neves LM, Santos ABL, Araújo FG. Distribution and size of the mojarra Diapterus rhombeus (Cuvier) (Actinopterygii, Gerreidade) in a Southeastern Brazilian bay. Braz J Ocean. 2012;60:199-207.

35. Reis-Filho JA, Santos ACA. Effects of substratum type on fish assemblages in shallow areas of a tropical estuary. Mar Ecol. 2014;35:456-70.

36. Aguirre-León A, Yánez-Arancibia A, Amescua-Linares F. Taxonomía, diversidad, distribución y abundancia delas mojarras de la Laguna de Términos, campeche (Pises:Gerreidae). An Inst Cien Mar y Limn, Univesidad Autónoma del México, México, 13:369-444. 1986
37. Araújo FG, Santos ACA. Distribution and recruitment of mojarras (Perciformes, Gerreidae) in the continental margin of Sepetiba Bay, Brazil. Bull Mar Sci. 1999:65:431-9.

38. Araújo FG, Azevedo MCC. Assemblage of southeast-south Brazilian coastal systems based on the distribution of fishes. Est Coast Shelf Sci. 2001;52:729-38.
Ready to submit your research? Choose BMC and benefit from:

- fast, convenient online submission

- thorough peer review by experienced researchers in your field

- rapid publication on acceptance

- support for research data, including large and complex data types

- gold Open Access which fosters wider collaboration and increased citations

- maximum visibility for your research: over $100 \mathrm{M}$ website views per year

At BMC, research is always in progress.

Learn more biomedcentral.com/submissions 